Marquette University

e-Publications@Marquette

Political Science Faculty Research and Publications

Political Science, Department of

$1-1-2013$

\title{
Barack Obama and the Rhetoric of Electoral Logic
}

Julia R.Azari

Marquette University, julia.azari@marquette.edu

Justin S. Vaughn

Boise State University

Accepted version. Social Science Quarterly, Vol. 95, No. 2 (June 2013): 523-540. DOI. (C 2013 John Wiley \& Sons, Inc. Used with permission. 
Marquette University

\title{
e-Publications@Marquette
}

\section{Political Science Faculty Research and Publications/College of Arts and Sciences}

This paper is NOT THE PUBLISHED VERSION; but the author's final, peer-reviewed manuscript. The published version may be accessed by following the link in the citation below.

Social Science Quarterly, Vol. 95, No. 2 (June, 2014): 523-540. DOI. This article is (C) Wiley and permission has been granted for this version to appear in e-Publications@Marquette. Wiley does not grant permission for this article to be further copied/distributed or hosted elsewhere without the express permission from Wiley.

\section{Barack Obama and the Rhetoric of Electoral Logic ${ }^{ \pm}$}

\author{
Julia R. Azari \\ Marquette University, Milwaukee, WI \\ Justin S. Vaughn \\ Boise State University
}

\section{Abstract \\ Objectives}

This article examines Barack Obama's efforts to interpret and characterize the contrasting outcomes of the 2008 and 2010 elections, using an original data set of presidential communications.

Methods

We performed a content analysis of 241 presidential communications.

\section{Results}

Obama's post-2008 mandate claims alternated between claiming a mandate on a variety of policy issues and framing the election as a repudiation of Republican theories of governing. Post-2010, however, 
Obama framed the midterm results as evidence for electoral demand for bipartisan cooperation, rather than a repudiation of Democratic policies and ideas.

\section{Conclusions}

Obama's choices in framing the 2008 election contributed to the administration's failure to communicate effectively. Specifically, Obama neglected to create a strong narrative linking the election's results to support for his policy agenda, focusing instead on the election as a repudiation of Republican policies. In contrast, his interpretations of the 2010 midterms appear to be more effective. By identifying the Republicans' behavior as "dysfunctional" and conceding that the election had indicated a demand for the ideas of both parties, Obama offered a more successful alternative to the Republican narrative.

Humility is not a characteristic we often associate with presidential leadership. Yet, that is precisely what the American people observed in full as Barack Obama delivered his remarks on November 3, 2010 , in a press statement the day after his party took what the president described as a "shellacking" in the midterm elections. The president's "pensive and introspective" demeanor alone would have been noteworthy (Rowland, 2010), but was especially so as a stark counterpoint to the way he had referenced the results of his own election two years earlier. This was particularly evident in moments such as when he allegedly told then-House of Representatives Minority Whip Republican Eric Cantor "I won" during a heated conversation about tax credits to be included in the 2009 economic recovery package (Khan, 2009; Alter, 2010:117) or when he later reminded his former general election opponent, Republican Senator John McCain, that the 2008 election was over during a health-care summit when McCain complained about the way key deals in the pending legislation provided special provisions for states such as Nebraska and Louisiana (Negrin and Hunt, 2010).

Certainly, these were not the first times a president attempted to frame the results of elections for important audiences, whether they be the national electorate watching on television at home or fellow policymakers in a White House meeting room. Presidents have long sought to interpret election outcomes, to claim mandates in victory, and to provide meaning in times of setback. Even so, key questions remain about these efforts, from how presidents endeavor to frame election results rhetorically and translate them into the basis for governing decisions to what effects these mandatesand presidential claims to their presence-have on governing.

We contend that presidents can attempt to frame the election as a party victory, an endorsement of specific policy proposals, or a call to higher ideals. Alternatively, they may also choose to eschew references to the election altogether once it has concluded, opting instead to provide a different basis for their governing decisions. We examine Barack Obama's efforts to frame the 2008 election as he sought to transition from campaigning to governing in a deeply polarized political context. We then consider Obama's efforts to respond to the $\mathbf{2 0 1 0}$ midterm losses, a topic less traveled in the mandates literature. We find that Obama's overall narrative in early 2009 stressed a partisan, repudiative interpretation of the election as a rejection of Republican economic theories as he proceeded to incorporate into his mandate narrative a wide range of policy issues that lacked a central unifying idea, an approach that would ultimately result in lost opportunities for leadership. However, we also find that after the $\mathbf{2 0 1 0}$ midterms, Obama adapted these same frames to interpret Republican victories, narrowed the policy focus of his claims, and was better able to manage the political narrative. 


\section{Mandates and Presidential Leadership: A Developing Debate}

Scholars have reconciled the persistence of the presidential mandate idea with the empirical challenges the concept poses by suggesting that mandates are a matter of framing and perception (Grossback, Peterson, and Stimson, 2005, 2007; Jones, 2005). As such, mandates exist primarily as the product of narrative, or in Grossback, Peterson, and Stimson's (2007:14) term, "social constructions." Conley (2001:2) describes mandates as both constructed and empirical linkages among Congress, the president, and the electorate: "Claiming a mandate is the equivalent of putting a major policy change on the national agenda. It is also a signal that the president believes he can rally support for his agenda; he will not attempt to change policy if he thinks he will fail. Mandate claims therefore depend upon a subjective reading of electoral and congressional support and upon a calculation of the potential for policy success." Claibourn takes a different approach, suggesting election messages matter a great deal for presidential accountability because citizens, early in a new term, will evaluate the president based on how well he adheres to the policy agenda expressed in his campaign (Claibourn, 2011:18-19).

Importantly, presidential interpretation of elections is not confined to the decision about whether to claim a mandate. Presidents have a range of options for interpreting elections, options that constitute what we refer to as the rhetoric of electoral logic. The simplest option, of course, is to avoid talking about the election result at all, justifying policy choices in other terms. However, if presidents do choose to frame their actions in terms of electoral logic, they may claim the election was a mandate for a candidate, for a party, for policy, a particular set of ideas, or some combination of these (Hershey, 1994). The approach they take can be shaped as much by the context of their victory as their approach to leadership. A related but distinct issue concerns the target and scope of the mandate. Some presidents focus their mandate talk on a particular issue or related set of issues, while others choose to frame the election in terms of broad governing principles.

Why do these rhetorical choices matter? Although rhetoric about mandates may not persuade voters or legislators that an election conferred a mandate, or change views on a specific policy issue, such rhetoric may be able to place policy action in a broader narrative of governance. Presidents can use electoral logic to justify attention to particular issues, to link issues under a central idea, or to explain policy choices in terms of either a partisan victory or shared bipartisan values. Indeed, scholarship suggests that presidential rhetoric can be effective as a means of framing (Druckman and Holmes, 2004), and, to a more limited extent, in setting the policy agenda (Peake and Eshbaugh-Soha, 2008).

In a divided polity, these frames can define how the president's agenda fits into existing party conflict. The impact of polarization on the presidency casts doubt on the possibilities for shaping political definition, with alliances clearly delineated around party lines (Skinner, 2009; Cameron, 2002). Yet, we contend that several possible outcomes exist. Presidents' rhetorical choices can frame policies in ways that reinforce polarized understandings of politics, casting policy in terms of the clear alternatives presented to the voters during the election. Alternately, they can choose to seek common ground, either by identifying broader values, or by emphasizing how closely divided the polity remains after a hard-fought election, acknowledging both sides' supporters.

Claiming an electoral mandate provides presidents with the opportunity to define policy choices in terms of a broader agenda. In a classic example, Ronald Reagan incorporated his proposals on taxes and efficiency in the federal government into a larger narrative of the conservative mandate of the 1980 election. Reagan's vanishingly small popular majority notwithstanding (Dahl, 1990), the narrative 
contextualized individual policy choices and shaped how others understood his presidency. This effective and cohesive narrative helped define Reagan's conservative "revolution" and recast the terms of debate in politics thereafter (Skowronek, 1997, 2011). Other presidents aspire to similar effects, though context and skill often constrain their ability to do so.

\section{Barack Obama's Rhetoric of Electoral Logic}

Barack Obama provides a particularly useful case for analyzing how presidents interpret elections in the context of party polarization. Although congressional voting behavior and public opinion remained divided by party, Obama faced expectations that he would employ his considerable rhetorical skill in order to frame policies in terms of "higher ideals and moral values," thus engaging in "transformative" leadership (Engbers and Fucilla, 2012:1133). Our study of his electoral logic rhetoric is therefore rooted in the question of how he addressed party divisions when discussing the Democratic victories of 2008 and the subsequent Republican victories in 2010, and how he incorporated narratives about these elections into public arguments about policy.

The 2008 election resulted in significant victories for Democratic candidates across the board. Obama also became the first Democratic presidential candidate since Jimmy Carter to win a majority of the popular vote; his 53.7 percent was the largest majority for a Democrat since Lyndon Johnson in 1964. The 44th president was also the first northern liberal Democrat to be elected since John F. Kennedy in 1960 , signaling a possible shift in the country's ideological direction. Nevertheless, the election also lent itself to alternative interpretations: as George W. Bush's approval ratings remained below 40 percent throughout his final year in office and plummeted into the 20 s after the financial crisis in 2008, the decline of the Republican "brand" was evident. During the fall of 2008, John McCain's choice of running mate, Alaska governor Sarah Palin, also detracted from his support as interviews revealed Palin to be illprepared to deal with pressing national issues, a development that was reinforced by McCain's own erratic response to the Lehman Brothers collapse soon after. These events suggested the election result might not reflect public embrace of Obama's policy stances; rather, Obama's victory might more accurately constitute a rejection of the Republican ticket for reasons related to the candidates themselves and to the previous administration.

In addition to Obama's 2008 victory, we also look at how he attempted to frame the midterm elections of 2010, an instructive case for several reasons. As with the period after the president's inauguration, the electorate had just emerged from a divisive campaign and the political environment remained polarized in on politics and policy. However, unlike the 2009 case, Obama's postmidterm rhetoric exemplifies an attempt to control the political narrative under unfavorable circumstances. It also illustrates the possibilities for, and the difficulties associated with, developing counterclaims to opponents' arguments in favor of a party mandate after an election victory.

To analyze Obama's rhetorical approach to explaining the results of the 2008 and 2010 elections, we use data from the Public Papers of the Presidency (available publicly online through the American

Presidency Project at 〈www.presidency.ucsb.edu $\rangle$ ), which we use to code communications over two relevant 12-week spans: his first 12 weeks in office after his 2009 inauguration and the 12 weeks following the 2010 midterm elections. Limiting each data set to 12 weeks balances the need to collect an adequate sample with the demands of an extensive coding effort. The purpose of our coding effort is to assign one of two scores to the communications in the data set: a score of 1 indicates the inclusion of 
mandate or electoral logic rhetoric, 0 indicates no such rhetoric. Scores were assigned based on whether communication used the election results, the promises of the campaign, or the will of the people as expressed in the election. Several keywords and phrases recurred in addition to the word "mandate"; we looked for "reason I was elected," "promises in my campaign," and "what the people voted for last November." Our coding efforts were qualitative, which means that our decisions were made based on a final judgment about whether the election was used as justification for policy action.

We applied the same logic to Obama's interpretation of the 2010 election, although the operationalization was somewhat different due to the changed context. Because Obama was unlikely to make references to the 2010 elections as a mandate for his policies or to his campaign (as he had not been running for office), we did not focus on these types of statements. Instead, we looked for Obama's attempts to interpret the meaning of the midterm elections in a way that was most favorable (or at least less unfavorable) to his agenda. Falling under the broad conceptual heading of electoral logic, postmidterm rhetoric included counterclaims to Republican arguments about the meaning of the 2010 elections. In assessing this rhetoric, we looked for language that tried to explain what "the people voted for" (or did not vote for) and "doing what we were elected to do," as well as any argument about the message sent by voters.

The central question that drove coding decisions was whether the election was used as a justification for policy action. Communications were coded as including a mandate claim if they linked a course of presidential action to responding to the demands of the electorate or fulfilling a campaign promise. Many communications coded as containing mandate language included an attempt to define "what the election was really about." In other instances, electoral logic took the form of stressing that the president had campaigned on a particular issue. After we determined whether a communication included electoral logic rhetoric, we identified whether the election was characterized as a party mandate: Did the president refer to the party platform (i.e., emphasize the differences between the two parties) or use mandate rhetoric to frame one of the party's signature issues (such as health-care reform)? We also classified electoral logic rhetoric by issue content and classified the various communications as one of seven different kinds of speech types: major speeches, minor remarks and communications, weekly radio/Internet addresses, speeches to party audiences, interactions with the media, government communications, and ceremonial speeches. Finally, to ensure the reliability of our data, a graduate research assistant independently replicated our coding scheme. In order to test reliability, we calculated the Cronbach's alpha coefficient between the two coders, a standard reliability measure used in political science (see Lawson et al., 2010; Davis and Brown, 2002; Kinder and Kiewiet, 1979). For the 2008 election data, the Cronbach's $\alpha$ for the two coders was 0.77; for the 2010 election data, Cronbach's a was 0.749. Both scores meet the standard threshold of 0.7 (Bernardi 1994).

\section{Translating 2008: Obama Claims a Mandate}

After the 2008 election, as we have noted above, Obama faced a number of possibilities about how to frame his victory. In light of talk during the campaign about a "postpartisan" presidency, Obama might have interpreted the election as a call for new terms of debate. At the same time, Obama's campaign promises to reverse substantial parts of Bush Administration policy, paired with Democratic victories across the electoral map, made claiming a party mandate also an option. Following his inauguration, Obama made references to the election and campaign in 25 different speeches over his first 12 weeks in office, or about 18 percent of the 138 public communications made during this period. Nearly half of 
these messages came in the form of minor addresses and remarks (67), with addresses to other governing elites (31), media interactions (24), and weekly radio/Internet addresses (10) being the next most frequent forms of White House communication during our 2009 sample. As shown in Table 1 , Obama's level of mandate rhetoric was generally consistent across his minor addresses, media interactions, and communications with other governing elites, with the percentage of mandate rhetoric varying from 12.5 percent to 16.1 percent in these categories. Speeches at party events and his weekly radio/Internet addresses featured significantly higher proportions of mandate rhetoric-100 percent and 40 percent, respectively-an observation that is unsurprising, given the partisan nature of both categories of speech types.

Table 1. The Audience Breakdown for Barack Obama's 2009 Mandate Claims

\begin{tabular}{|l|l|l|l|}
\hline Category & $\begin{array}{l}\text { Total Number Communications in } \\
\text { Category }\end{array}$ & $\begin{array}{l}\text { Total Number Including } \\
\text { Mandate Rhetoric }\end{array}$ & Percentage \\
\hline Major addresses & 1 & 0 & 0 \\
\hline $\begin{array}{l}\text { News/media } \\
\text { interactions }\end{array}$ & 24 & 3 & 12.5 \\
\hline $\begin{array}{l}\text { Minor } \\
\text { addresses/remarks }\end{array}$ & 67 & 10 & 14.9 \\
\hline Weekly radio address & 10 & 4 & 40 \\
\hline Party event & 3 & 3 & 100 \\
\hline Government & 31 & 5 & 16.1 \\
\hline Ceremonial & 2 & 0 & 0 \\
\hline
\end{tabular}

Two major features stand out with regard to Obama's mandate claims during this period. First, he referred to several different issues as either the reason for his election or as a central promise of the campaign, rather than linking his mandate to a core policy initiative. Second, although Olson et al. (2012) have recently shown that Obama's general level of rhetorical inclusiveness versus exclusiveness did not change as he transitioned from campaigning to governing, it is clear that his references to the election quickly lost the postpartisan veneer that characterized much of his campaign season rhetoric as he pivoted to an explanation of the outcome as a repudiation of Republican theories of governance, with his remarks offering little in the way of reframing old issues or reimagining party divisions (see also Rudalevige, 2012). In the sections that follow, we discuss each feature in turn.

\section{Claiming a Multi-Issue Mandate}

Economic issues constituted the main issue area in which Candidate Obama sought to distinguish his leadership from that of the Bush Administration. Furthermore, major economic events during the general election and his "presidential" response to them vis-à-vis his opponent's erratic reactions played a significant role in helping cement his victory (Abramowitz, 2010:99-101; Alexander, 2010:243-66). Despite these factors, Obama did not restrict his interpretation of the 2008 election's outcome to 
economic matters. Between January 20 and March 31, 2009, Obama referred to seven distinct policy areas in terms of his campaign promises or the demand of the electorate (see Table 2 ). Although economic themes dominate any other specific issue, economic-related mandate claims only account for 40 percent of all mandate claims; a majority of Obama's claims dealt with either other policy issues or were more general statements about a mandate for his agenda broadly construed.

Table 2. The Focus of Barack Obama's 2009 Mandate Claims

\begin{tabular}{|l|l|}
\hline Issue & Mandate Mentions \\
\hline Good government & 2 \\
\hline Economy & 10 \\
\hline Overall unspecified agenda & 4 \\
\hline Defense/war on terror & 3 \\
\hline Taxes & 3 \\
\hline Energy & 1 \\
\hline Stem cell research & 1 \\
\hline National service program & 1 \\
\hline
\end{tabular}

Included among these mandate claims were statements that he had been elected to curb the influence of special interests in the White House (Remarks on the Federal Budget, February 26), along with a variety of other issues, including taxes, energy, and stem cell research (President's Weekly Address, February 21; Interview with Regional Reporters, March 11; Remarks on Signing an Executive Order Removing Barriers to Responsible Scientific Research Involving Human Stem Cells and a Memorandum on Scientific Integrity, March 9). Obama also claimed to have been elected on the basis of his positions on foreign policy and the War on Terror (Interview with Jim Lehrer, February 27; Remarks on Military Operations in Iraq at Camp Lejeune, North Carolina, February 27; Remarks Following a Meeting with Retired Military Officers, January 22), areas in which he had taken pains during the campaign to distinguish himself not only from Republicans George W. Bush and John McCain, but also from his main opponent for the Democratic nomination, Hillary Clinton. In public speeches and news interviews, Obama emphasized his efforts to fulfill campaign promises by signing an executive order to close Guantanamo Bay. He also claimed that the campaign had illuminated his positions on the Iraq timeline, thus justifying his choices about how to handle the conflict. Similarly, Obama also suggested that the election had been an endorsement of an unspecified agenda around the theme of change. For example, in remarks on the federal budget in March 2009, Obama explained some of his budgetary prioritiesincluding education, alternative energy, and healthcare-before concluding: "The American people sent us here to get things done, and at this moment of enormous challenge, they are watching and waiting for us to lead. Let's show them that we are equal to the task before us, and let's pass a budget that puts this Nation on the road to lasting prosperity."

Although observers may suggest Obama's interpretation of the election as justification for his entire agenda ignored some of the empirical realities of the outcome, it is not surprising that Obama offered his electoral victory as evidence of public support for a wide range of his policy initiatives. Presidents 
wield an array of rhetorical arguments when attempting to lead, particularly when those arguments have an air of reasonableness. Less predictable, however, was the extent to which this rhetoric focused on the electorate's repudiation of the previous administration.

\section{Claiming a Partisan Mandate}

In his victory speech on November 4, 2008, Barack Obama made a promise: "And to those Americans whose support I have yet to earn-I may not have won your vote, but I hear your voices, I need your help, and I will be your President too." In the victory speech, Obama describes a presidency "above" partisan politics, in which supporters bring a president to office, but governing choices respond to a more nationally inclusive set of values. By contrast, Obama's "I won" comment in the context of policy battles with Republicans, mentioned in the introduction of this article, suggests an approach in which policy approaches are ratified in the voting booth, and the president, as leader of the victorious party, pushes to enact its platform. For example, in his speeches on economic policy, Obama offered up Republican ideas as foils for his own, and suggested that the electorate had "rejected these theories." In a speech to House Democrats on February 5, 2009, Obama stated:

"We can't embrace the losing formula that says only tax cuts will work for every problem we face, that ignores critical challenges like our addiction to foreign oil, or the soaring cost of health care, or falling schools and crumbling bridges and roads and levees. I don't care whether you're driving a hybrid or an SUV, if you're headed for a cliff, you've got to change direction. That's what the American people called for in November, and that's what we intend to deliver."

Even when he was not in front of a partisan audience, Obama emphasized how the electorate had "rejected" Republican economic ideas when they voted for change in 2008. This trope was repeated in remarks after signing the reauthorization of the Children's Health Insurance Program (February 4), in a speech to the Department of Energy (February 5), and in general remarks on the national economy (February 4). Yet, throughout these speeches, while Obama argued that the people had voted against old ideas, he generally refrained from specifying the content of new ones. In his February 4 remarks on the national economy, for example, Obama dismissed critics of the American Recovery and Reinvestment Act of 2009, attributing to them "the notion that tax cuts alone will solve all our problems; that we can ignore fundamental challenges like energy independence and the high cost of health care; that we can somehow deal with this in a piecemeal fashion and still expect our economy and our country to thrive." Placing his refutation of these ideas within the context of his mandate narrative, Obama went on to say, "I reject those theories, and so did the American people when they went to the polls in November and voted resoundingly for change." But the rest of the remarks neglected to offer an alternate theory; rather than offer criticisms of the behavior of the financial industry, Obama instead provided assurances to the audience that Americans do not "disparage wealth." Indeed, as Hoffman and Howard (2012) show in their analysis of this speech (along with his three subsequent State of the Union Addresses), Obama largely focused on large if general ideas, preferring to leave the policy details to others in the legislative branch. Further, Obama's 2009 contribution to this genre marked his least substantive of the four during his first term, as evidenced by notably fewer specific policy requests than any other year (Hoffman and Howard, 2012:1326-28).

The choice between a more partisan approach or a more unifying one tapped into questions about what kind of presidency Obama's would be. During the campaign, Obama offered the promise of a "postpartisan" presidency, an idea that would soon be supplanted by the harsh reality of continuing 
polarization. Indeed, Obama's presidency quickly proved, by some measures, to be more polarizing than that of George W. Bush, with an even wider "approval gap" between Republicans and Democrats (Jones, 2010). The possibility of a "postpartisan" presidency speaks directly to the notion of presidential problem-solving, and as Obama presented himself to the public as a pragmatist who would make addressing the nation's problems his priority, expectations he do so rose accordingly (Saad, 2009; Mercieca and Vaughn, 2012).

Meeting these expectations would have required Obama to demonstrate considerable skill in brokering compromise, skills that seemed to be in abeyance (Vaughn, 2011) in part due to the intransigence of his partisan opposition, but in part due also to Obama's framing approach. In the age of the permanent campaign, brokering compromise across party lines would likely require reframing previously divisive issues in ways that would make them appealing for both Democrats and (at least some) Republicans. Numerous scholars have suggested that the polarized political environment limited Obama's ability to cross party lines (Campbell, 2012; Jacobson, 2012; Cohen and Panagopoulos, 2011); our evidence does nothing to refute this. However, examination of some of Obama's earliest comments in office reveals that, contrary to his campaign-season appeals to postpartisanship, he often set up Republican ideas in contrast to his own, leaving little room for compromise (see also Edwards, 2012a:43-44).

Indeed, as Obama developed his communication strategy in the early months of 2009, he moved decidedly toward the "I won" stance. He repeated the refrain, "these ideas have been tested, and they have failed," and suggested that Republican policy had driven the country "off a cliff." Using strikingly similar language before party audiences and in more general remarks, Obama framed the election as a repudiation of Republican ideas. Repudiation, Skowronek (1997:36) argues, is central to transformative or reconstructive leadership; only those presidents who can establish the right to make a break with the past can fundamentally alter the polity. Yet, the Obama case illustrates how repudiation alone is not sufficient for such leadership. By focusing so much attention on the rejection of Republican ideas, Obama's words contributed to their entrenchment as the dominant frame for policy debate.

Compare, for example, Obama's statement that "I reject these theories, and so did the American people when they voted resoundingly for change" with Reagan's framing of the 1980 election as a policy mandate. In a message to Congress on March 10, 1981, about fiscal year 1982 budget revisions, Reagan explicitly guides Congress by claiming a mandate for change: "When considering the economic recovery package, I urge the Members of Congress to remember that last November the American people's message was loud and clear. The mandate for change, expressed by the American people, was not my mandate; it was our mandate. Together we must remember that our primary responsibility is to the Nation as a whole and that there is nothing more important than putting America's economic house in order." As with Obama in 2009, Reagan sought to distinguish his own approach from that of his discredited predecessor. At the same time, his rhetoric focused on the positive aspects of the new proposals as well as the unfavorable comparisons with the recent past. Reagan also placed economic policy within a larger set of ideas about American politics and society.

As Skowronek (1997:37) describes, transformational presidents can take advantage of reconstructive opportunities to not only change the substantive direction of policy, but also to frame policies in terms of a return to "first principles" and a reaffirmation of the nation's "far distant, even mythic, past fundamental values." Similarly, Bert Rockman notes that transformational leaders "may negotiate, but always with the broader picture in mind" (2012:1067). In this regard, Reagan depicted changes to 
economic policy as part of a return to fundamental national values. For Obama, demonstrating a negative break was not enough. He repeatedly emphasized that Republican ideas "had been tested" and "failed." However, without a clear explanation of the ideas behind his alternative proposals, Obama remained vulnerable, and Republican efforts to frame the administration's signature policies in terms of taxes and excessive government control proved very successful. Obama's party experienced major losses in the $\mathbf{2 0 1 0}$ midterm elections, fundamentally altering the president's strategic leadership context and prompting another occasion for him to explain and frame an election for voters and political elites alike.

\section{The Shellacking: Obama Explains the 2010 Elections}

The Obama case also allows us to assess a conceptually related, but substantively distinct question: How do presidents publicly interpret midterm elections that present their parties with significant losses in Congress? The party of the president usually loses seats in midterm elections, and the Democrats in 2010 were especially vulnerable. When election night brought a 60-seat loss for the Democrats in the House of Representatives and a 60-seat loss in the Senate, it was difficult to identify the election as anything but a blow to the Obama Administration. In a press conference the next day, Obama admitted as much, calling the election a "shellacking" for his party and himself. Beyond this turn of phrase, which occupied news commentators for a day or two, Obama faced a choice about how to deal with these results. He could choose to ignore the election result and talk about other things. Alternatively, he could accept the Republican interpretation of the election as a rebuke to his own political agenda and restructure his preferences accordingly, although this would have been politically fraught and, in any case, highly unlikely. Instead of either of these options, he attempted to co-opt the election's outcome.

Obama made references to the election and its outcome in 11 different speeches over the 12 weeks following the midterms, or about 10.5 percent of the 103 public communications made during this period. As was the case with his interpretations of his 2008 victory, the greatest number of communications in this sample were in the form of minor addresses and remarks (57), followed by communications to other governing elites (16), media interactions (15), and weekly radio/Internet addresses (11) (see Table $\underline{\mathbf{3}}$ ). Notably distinct from the previous sample, however, is the way Obama used various speech types to different degrees as he interpreted the Republican victory in 2010. For example, the percentage of mandate rhetoric in Obama's minor addresses dropped from 14.9 percent to 8.8 percent, while a similar decline was evident in his weekly addresses, which fell from 40 percent to 8.3 percent. Conversely, Obama's focus on electoral interpretation in his interactions with the media doubled, as it increased from 12.5 percent to 26.7 percent. He also referred to the midterm elections in his 2011 State of the Union Address.

Table 3. The Audience Breakdown for Barack Obama's 2010 Midterm Interpretations

\begin{tabular}{|l|l|l|l|}
\hline Category & $\begin{array}{l}\text { Total Number Communications In } \\
\text { Category }\end{array}$ & $\begin{array}{l}\text { Total Number Including } \\
\text { Mandate Rhetoric }\end{array}$ & Percentage \\
\hline Major addresses & 1 & 1 & 100 \\
\hline $\begin{array}{l}\text { News/media } \\
\text { interactions }\end{array}$ & 15 & 4 & 26.7 \\
\hline
\end{tabular}




\begin{tabular}{|l|l|l|l|}
\hline $\begin{array}{l}\text { Minor } \\
\text { addresses/remarks }\end{array}$ & 57 & 5 & 8.8 \\
\hline Weekly radio addresses & 12 & 1 & 8.3 \\
\hline Party event & 0 & 0 & NA \\
\hline Government & 17 & 0 & 0 \\
\hline Ceremonial & 1 & 0 & 0 \\
\hline
\end{tabular}

Obama's venue selection was not the only way his approach to interpreting the 2010 midterms changed from his efforts to explain 2008. The issue focus and approach to party divisions also differed across the two contexts. First, where Obama had claimed a multi-issue mandate following his 2008 victory, his postmidterm rhetoric focused on countering the Republican narrative of the election as a rejection of Obama's policies, particularly his signature health-care reform legislation.

As Table $\underline{4}$ shows, Obama's rhetoric about the 2010 election encompassed several themes. As he had after his 2008 victory, he acknowledged the role that economic dissatisfaction had played in the election result. The other dominant theme in Obama's interpretations of the 2010 election was that the public had not voted for gridlock, but rather for progress and problem solving. Once again, the issues that were associated with this mandate for progress varied widely, including tax legislation and the ratification of the new START treaty. Only once did the president acknowledge that the actions or failures of his administration might have contributed to Republican victories. In an interview with Steve Kroft on Sixty Minutes, Obama noted, "I think that what happened over the course of two years was that we had to take a series of big emergency steps quickly, and most of them in the first six months of my administration. Each of them had a big price tag, and people looked at that and they said, 'Boy, this feels as if there's a huge expansion of government."' In other words, Obama attributed the election losses to dissatisfaction with the economy, rejection of partisan politics, and failure to communicate effectively about administration policy, but he carefully deflected suggestions that the policy itself might have produced a backlash.

Table 4. The Focus of Barack Obama's Interpretations of the 2010 Election

\begin{tabular}{|l|l|}
\hline Issue & Midterm Election Mentions \\
\hline Economy & 4 \\
\hline Cooperation & 2 \\
\hline Progress & 4 \\
\hline Failure to communicate about policies & 1 \\
\hline
\end{tabular}

Second, as one might expect, Obama approached the topic of party politics differently after the 2010 elections as well. His rhetoric acknowledged the imminence of divided government, such as "cooperation." In his weekly radio address on November 6, Obama stated: "This week, Americans across the country cast their votes and made their voices heard. And your message was clear. You're rightly frustrated with the pace of our economic recovery. So am I. You're fed up with partisan politics and 
want results. I do too." Using these words, Obama countered Republican interpretations of the election with one of his own, which built on his narrative of the 2008 election as an expression of public frustration with the economy and the political status quo. The 2010 midterms, he maintained, had emanated from the same feelings and perceptions among the voters. Expanding on this logic, Obama maintained later that the people had voted for "divided government, not dysfunctional government." This phrase became one of Obama's speech standards as he used variations of it for several months. He repeated this line in town hall meetings, at Democratic fundraisers, and in several national speeches, including his weekly radio address and, most notably, a televised address to the nation on the federal budget. By repeatedly arguing that the 2010 elections had been a call for cooperation between the two parties, Obama acknowledged the Republican victory while simultaneously reminding audiences that the Democrats had enjoyed important victories only two years before and still held a legitimate claim to power, thus challenging Republican claims to a party mandate of their own.

How did Obama's efforts to frame the 2010 midterms compare to the narrative about the 2008 election? As with 2008, Obama primarily framed the midterms as a rejection of the past. He also linked the election result to several issues and ideas, although this served a different purpose than in 2009. After the midterm, it served as a counterclaim to Republican arguments that the elections were a referendum on health-care reform and the president's economic policies. In contrast with his post-2008 rhetoric, however, Obama's words emphasized pragmatic concerns over governing philosophies. It is difficult to determine whether Obama succeeded in gaining control over the political narrative after the 2010 elections. However, there is some evidence that Obama's frames were more consistent with public attitudes after 2010 than after 2008. For example, citizens' evaluations of the Tea Party began to turn negative during the early months of 2011 (Newport, 2011), suggesting that the idea of a conservative mandate from the 2010 election had not taken hold in the public mind and that a more ideological approach to politics was not welcome from either end of the ideological spectrum. Public attitudes in 2011 also experienced a temporary pause in the expansion of the polarization of attitudes toward the president. Obama's "approval gap" also held steady between January 2010 and January 2012 at a 68point difference between Democrats and Republicans, after widening three points between 2009 and 2010 (it also expanded to a 76 percentage point difference in 2012). Finally, the 2012 elections maintained the status quo in the House of Representatives, the Senate, and the White House, returning to power a divided government and a president with a small popular majority. Obama's rhetoric after the 2010 election suggests a turn away from frames that reflected and reinforced the depth of political divisions, and instead toward frames that acknowledged the narrowness of those divisions and the tenuousness of either party's claim to a popular majority.

\section{Conclusion}

Coming into office 28 years after Ronald Reagan's "revolution" that reversed many New-Deal-era governing ideas, some observers suggested that Barack Obama might have the potential to transform the nation's commitments and priorities once again. To be sure, Obama can boast a lengthy list of firstterm major domestic policy accomplishments, including a successful auto industry rescue and the passage of health-care reform. He can cite both the formal withdrawal of troops from Iraq and the death of Osama bin Laden as major foreign policy and national security accomplishments. John Davis (2011:42) observes that, "under normal circumstances, Obama's achievements would point to a historic legacy," but attributes the administration's struggles to define itself politically as the result of political conditions, 
namely, the economy and the polarized political climate. As Skowronek (1997) notes, concrete achievements are insufficient to transform politics; most presidents accomplish a great deal, but not all are graced with equal opportunities to define their achievements. However, the evidence presented here suggests that Obama's own communications may also be partly to blame.

During his first term, Obama was in the position of interpreting first an election that brought his party considerable success, and then an election in which his party suffered a humbling defeat. Our analysis of Obama's rhetoric reveals that his interpretations of these two different contests share a common thread: in both cases, he suggested that the driving force behind voters' choices was frustration with the status quo. After the 2008 election, this approach appears to have been a missed opportunity to define his policy choices in more persuasive and principled terms. We suggest that by associating the 2008 election and campaign with a wide yet loosely connected range of issues, Obama missed an opportunity to develop an overarching theme to define his achievements. Similarly, by emphasizing the failures of the previous administration, Obama did little to help develop a broader narrative of the 2008 election as a mandate for his own policy vision.

In contrast, however, Obama's narrative about the 2010 midterms seems to have served its purpose. Obama's communication strategy drew on some of the same ideas as in 2009: the idea of a frustrated electorate rejecting the status quo. The decision to invoke the election result both in the immediate aftermath of the midterm losses and later, during tense debates over national policy, is both surprising and potentially significant. By identifying Republican behavior as "dysfunctional" and conceding that the election indicated a demand for the ideas of both parties, Obama offered an alternative to the Republican narrative. Further, by focusing on economic issues after the 2010 election, as well as related ideas such as cooperation and progress, Obama showed a stronger sense of campaign accountability than after the 2008 election, when mandate rhetoric spanned a number of policy areas despite the perceived focus on the economy during the campaign. That said, it must also be acknowledged that perhaps Obama's different approaches to electoral logic in early 2009 and late 2010 were driven not so much by getting the message right, but instead by the possibility that it may just be easier to "play defense." After the midterm losses sustained by Obama's party, expectations for his policy leadership changed, and no longer was he saddled with the impossible task of claiming a mandate for change. Instead, he simply needed to frame the election's result in a way that refuted suggestions of Republican dominance.

Our analysis suggests that presidential interpretation of elections goes beyond the decision about whether to claim a mandate. Election interpretation offers presidents an opportunity to define a broad vision, but they may also opt for a more piecemeal approach. In a divided polity, presidents can interpret elections in ways that reinforce differences between the parties or use the election as a springboard for more inclusive frames. We find that less ambitious, more "transactional" approaches may work better for presidents in such circumstances, as these frames acknowledge differences in opinion while seeking avenues for collaboration.

Nevertheless, a fair and interesting question could be asked about what exactly Obama could have done differently to avoid the hurdles he encountered during his first term. As we have noted earlier, Obama departed from Reagan's approach in 1981 in that Obama's mandate rhetoric was limited to a negative repudiation of the Republican administration and its policy agenda. Beyond suggesting that a more positive frame might have yielded greater dividends, political science scholarship points to two other 
approaches Obama might have pursued, but did not. First, scholarship assessing the relative weakness of presidential powers has suggested that presidents might be best advised to avoid seeking out public leadership opportunities and instead focus on building coalitions by "staying private" (Edwards, 2000; Covington, 1987). Such an approach would potentially avoid the negative consequences of going public (i.e., engendering greater public opposition from one's partisan opponents), but would arguably be impossible in an era where presidents need to be seen speaking to the people.

For those reasons, future presidents may wish to take note of recent research showing that Congress has proven largely immune to mandate claims; what has mattered, in terms of presidential leadership of Congress, is basing appeals on the merits of the policy under consideration (Villalobos, Vaughn, and Azari, 2012). Of course, neither of these alternative approaches would have changed the on-the-ground realities of Obama's first term: an economic crisis, massive national debt, stark and growing polarization, and-in years three and four-a Republican-controlled House of Representatives

(Edwards, 2012b:1099). Counterfactuals aside, however a president chooses to proceed, interpreting election results presents presidents with an opportunity to manage the narrative around their policy achievements and to define the term of political conflict. Ironically, Obama appears to have chosen a more astute strategy in response to a loss, rather than in response to a victory.

\section{References}

Abramowitz, Alan. 2010. "The 2008 Presidential Election: How Obama Won and What It Means." Pp. 91114 in Larry J. Sabato, ed., The Year of Obama: How Barack Obama Won the White House. New York: Longman.

Alexander, Jeffrey C. 2010. The Performance of Politics: Obama's Victory and the Democratic Struggle for Power. Oxford: Oxford University Press.

Alter, Jonathan. 2010. The Promise: President Obama, Year One. New York: Simon and Schuster.

Bernardi, Richard A. 1994. "Validating Research Results When Cronbach's Alpha is Below .7: A Methodological Procedure." Educational and Psychological Measurement 54(3):766-75.

Cameron, Charles M. 2002. "Studying the Polarized Presidency." Presidential Studies Quarterly32(4):647-63.

Campbell, James E. 2012. "Political Forces on the Obama Presidency: From Elections to Governing." Pp. 67-93 in Bert A. Rockman, Andrew Rudalevige, and Colin Campbell, eds., The Obama Presidency: Appraisals and Prospects. Washington, DC: CQ Press.

Claibourn, Michele. 2011. Presidential Campaigns and Presidential Accountability. Champaign, IL: University of Illinois Press.

Cohen, Jeffrey E., and Costas Panagopoulos. 2011. "Presidential Leadership and Public Opinion in an Age of Polarization." Pp. 31-47 in Andrew J. Dowdle, Dirk C. van Raemdonck, and Robert Maranto, eds., The Obama Presidency: Change and Continuity. New York: Routledge.

Conley, Patricia Heidotting. 2001. Presidential Mandates: How Elections Set the National Agenda. Chicago, IL: University of Chicago Press.

Covington, Cary. R. 1987. "'Staying Private': Gaining Congressional Support for Unpublicized Presidential Preferences on Roll Call Votes." Journal of Politics 49(3):737-55.

Dahl, Robert. 1990. "The Myth of the Presidential Mandate." Political Science Quarterly 105:355-72. 
Davis, Darren W., and Ronald E. Brown. 2002. "The Antipathy of Black Nationalism: Behavioral and Attitudinal Implications of an African American Ideology." American Journal of Political Science 46(2):239-52.

Davis, John. 2011. "The Economic Stimulus, Health Care, and Financial Reform: Evaluating President Obama's Legislative Agenda." Pp. 31-46 in John Davis, ed., The Barack Obama Presidency: A Two Year Assessment. New York: Palgrave MacMillan.

Druckman, James N., and Justin W. Holmes. 2004. "Does Presidential Rhetoric Matter? Priming and Presidential Approval." Presidential Studies Quarterly 34(4):755-78.

Edwards, George C. III. 2000. "Coalition Building." Presidential Studies Quarterly 30(1):47-78.

Edwards, George C. III. 2012a. "Strategic Assessments: Evaluating Opportunities and Strategies in the Obama Presidency." Pp. 37-66 in Bert A. Rockman, Andrew Rudalevige, and Colin Campbell, eds., The Obama Presidency: Appraisals and Prospects. Washington, DC: CQ Press.

Edwards, George C. III. 2012b. "Creating Opportunities? Bipartisanship in the Early Obama Presidency." Social Science Quarterly 93(5):1081-1100.

Engbers, Trent, and Louis Fucilla. 2012. "Transforming Leadership and the Obama Presidency." Social Science Quarterly 93(5):1127-45.

Grossback, Lawrence J., David A. M. Peterson, and James A. Stimson. 2005. "Comparing Competing Theories on the Causes of Mandate Perceptions." American Journal of Political Science 49(2):406-19.

Grossback, Lawrence J., David A. M. Peterson, and James A. Stimson. 2007. Mandate Politics. New York: Cambridge University Press.

Hershey, Marjorie Randon. 1994. "The Meaning of a Mandate: Interpretations of 'Mandate' in 1984 Presidential Election Coverage." Polity 27:225-54.

Hoffman, Donna R., and Allison D. Howard. 2012. "Obama in Words and Deeds." Social Science Quarterly 93(5):1316-37.

Jacobson, Gary C. 2012. "Polarization, Public Opinion, and the Presidency: The Obama and Anti-Obama Coalitions." Pp. 94-122 in Bert A. Rockman, Andrew Rudalevige, and Colin Campbell, eds., The Obama Presidency: Appraisals and Prospects. Washington, DC: CQ Press.

Jones, Charles O. 2005. The Presidency in a Separated System, 2nd ed. Washington, DC: Brookings Institution Press.

Jones, Jeffrey M. 2010. “Obama's Approval Most Polarized for First-Year President." Gallup News Service January 25.

Khan, Huma. 2009. "'I Won:' President Obama Works to Be Bipartisan But Shows There Are Clear Limits." ABC News. Available at 〈http://abcnews.go.com/blogs/politics/2009/01/i- wonpresident/>.

Kinder, Donald, and Ronald Kiewiet. 1979. "Economic Discontent and Political Behavior: The Role of Personal Grievances and Collective Economic Judgments in Congressional Voting." American Journal of Political Science 23(3):495-527.

Lawson, Chappell, Gabriel S. Lenz, Andy Baker, and Michael Myers. 2010. "Looking Like a Winner: Candidate Appearance and Electoral Success in New Democracies." World Politics 62(4):561-93.

Mercieca, Jennifer R., and Justin S. Vaughn. 2012. "Barack Obama and the Rhetoric of Heroic Expectations." Paper Prepared for Presentation at the Annual Meeting of the Western Political Science Association, Portland, OR. 
Negrin, Matt, and Kasie Hunt. 2010. "POTUS to McCain: 'Election's Over'." Politico. Available at 〈 http://www.politico.com/politico44/perm/0210/2008 all over again 2365b0f4-f42f-4b11a2b1-b7721e46951c.html〉.

Newport, Frank. 2011. “In U.S., Negative Views of the Tea Party Rise to All-Time High." Gallup News Service April 28.

Olson, Jeremiah, Yu Ouyang, John Poe, Austin Trantham, and Richard W. Waterman. 2012. "The Teleprompter Presidency: Comparing Obama's Campaign and Governing Rhetoric." Social Science Quarterly 93(5):1402-23.

Peake, Jeffrey S., and Matthew Eshbaugh-Soha. 2008. "The Agenda-Setting Impact of Major Presidential TV Addresses." Political Communication 113(2):113-37.

Rockman, Bert A. 2012. "The Obama Presidency: Hope, Change, and Reality." Social Science Quarterly 93(5):1065-80.

Rowland, Kara. 2010. "Obama Concedes 'Shellacking'." Washington Times. Available at 〈 http://www.washingtontimes.com/news/2010/nov/3/obama-concedes- shellacking/?page = all $>$.

Rudalevige, Andrew. 2012. "A Majority is the Best Repartee': Barack Obama and Congress, 20092012." Social Science Quarterly 93(5):1272-94.

Saad, Lydia. 2009. "Americans Confidence in Military Up, Banks Down." Gallup News Service June 24.

Skinner, Richard M. 2009. "George W. Bush and the Partisan Presidency." Political Science Quarterly123(4):605-22.

Skowronek, Stephen. 1997. The Politics Presidents Make: Leadership from John Adams to Bill Clinton. Cambridge, MA: Belknap Press of Harvard University.

Skowronek, Stephen. 2011. Presidential Leadership in Political Time: Reprise and Reappraisal, 2nd ed. Lawrence, KS: University Press of Kansas.

Vaughn, Justin S. 2011. "No Place for a Community Organizer: Barack Obama's Leadership of Congress." Pp 109-20 in Andrew J. Dowdle, Dirk C. van Raemdonck, and Robert Maranto, eds., The Obama Presidency: Change and Continuity. New York: Routledge.

Villalobos, José D., Justin S. Vaughn, and Julia R. Azari. 2012. "Politics or Policy? How Rhetoric Matters to Presidential Leadership of Congress." Presidential Studies Quarterly 42(3):549-76. 